\title{
Onde estão a religião e a política? Compreensões de jovens universitários católicos, evangélicos e sem religião
}

\author{
Where are religion and politics? Comprehensions of Catholic, Evangelical and \\ no religion university students
}

\author{
Cristina Satie de Oliveira Pátaro* \\ Frank Antonio Mezzomo**
}

\begin{abstract}
Resumo
A pesquisa aqui relatada problematiza a constituição das identidades juvenis na interface com as dimensões da religião e da política, buscando discutir as influências que as vivências e aprendizagens junto à Universidade trazem às compreensões dos jovens. São analisados dados de 203 estudantes de 30 ano de cursos de licenciatura da Universidade Estadual do Paraná, divididos em três grupos: católicos, evangélicos e sem religião. Os dados foram obtidos a partir de survey com questões abertas e fechadas, referentes às temáticas da religião, da política e das vivências junto à Graduação. Os resultados evidenciam compreensões compartilhadas pelos jovens dos três grupos analisados, além de tendências e especificidades no perfil e nas concepções de cada um deles. Verificou-se a relevância que os aspectos religiosos e a vivência universitária assumem para os jovens estudantes. Além disso, identifica-se uma representação que parece reforçar a separação entre política e religião, ao mesmo tempo em que se verificam, na constituição das identidades juvenis, permeabilizações e influências mútuas entre as duas esferas mencionadas.
\end{abstract}

Palavras-chave: jovens universitários; religião; política; universidade.

\begin{abstract}
The research problematizes the identities constitution in interface with dimensions of religion and politics, aiming at discuss the influences of experiences and learning at University on youths comprehensions. It is analyzed data of three groups of university students: Catholics, Evangelicals and no religion, obtained from a survey with questions related to religion, politics and University life experiences. The results evidence shared understandings among the young people of the three analyzed groups, as well as trends and specificities in the profile and conceptions of each one. It was verified the relevance that religious aspects and university experiences assume for young people. In addition, it was identified a representation that seems to reinforce the separation of politics and religion, at the same time as permeabilizations and mutual influences between the two spheres are verified in the youth identities constitution.
\end{abstract}

Keywords: youth university students; religion; politics; university.

Artigo recebido em 09 de julho de 2017 e aprovado em 28 de agosto de 2018.

* Doutora em Educação (USP). País de origem: Brasil. E-mail: crispataro@gmail.com

${ }^{* *}$ Doutor em História Cultural (UFSC). País de origem: Brasil. E-mail: frankmezzomo@gmail.com

Horizonte, Belo Horizonte, v. 16, n. 50, p. 812-844, maio/ago. 2018 - ISSN 2175-5841 


\section{Introdução}

As relações entre religião e política na contemporaneidade continuam gerando controvérsias, dissensos e disputas, em uma discussão que parece ainda longe de ser solucionada. Estão mais presentes do que nunca os debates que problematizam, no contexto de uma sociedade laica e democrática, até que ponto a religião pode ou não influenciar e estar presente no espaço público, nas questões do Estado, nas definições e princípios da educação, nos processos eleitorais, entre outros. Se na modernidade construiu-se um arrazoado acerca dos fins últimos do que seriam os campos da religião e da política - marcados por um entendimento dicotômico e maniqueísta das esferas privada e pública, respectivamente -, é notório que temos presenciado, cada vez mais, uma infinidade de situações institucionalizadas ou não - as quais acabam por borrar as supostas fronteiras entre ambos. Essa problemática, que impacta na dinâmica das instituições e dos centros de poder, demanda também novas formas de compreender as sociabilidades e as subjetividades no cenário contemporâneo.

Na esteira desta discussão, buscamos analisar, neste texto, de que forma as dimensões da religião e da política se fazem presentes no processo de constituição identitária de jovens universitários. Para tanto, nossa pesquisa enfoca, a partir da compreensão de estudantes católicos, evangélicos e sem religião, suas concepções sobre política e religião, bem como as influências promovidas pela vivência universitária em tais dimensões.

Nas últimas décadas, no Brasil, diferentes pesquisas vêm tematizando o perfil e as representações de jovens universitários acerca da religião e da política (NOVAES, 1994; STEIL; ALVES; HERRERA, 2001; SIMÕES, 2007; RIBEIRO, 2009; PÁTARO; MEZZOMO, 2013), possibilitando, a partir de tal intersecção, uma incursão em problemáticas sobre a pluralidade de vivências juvenis, as diversas formas de participação política - para além da via formal -, bem como as tensões entre secularização e reencantamento na esfera da religião (CAMURÇA, 2013).

Horizonte, Belo Horizonte, v. 16, n. 50, p. 812-844, maio/ago. 2018 - ISSN 2175-5841 
A sociedade contemporânea traz em seu bojo processos intensos de transformação, incertezas e risco, provocando novas reflexões acerca das instituições e das sociabilidades (BAUMAN, 2001; GIDDENS, 2002; MELUCCI, 2004; BECK, 2010). Diante de tal conjuntura, cabe indagar acerca do processo de constituição das identidades, tema que já vem sendo abordado por diferentes autores, os quais chamam a atenção para um entendimento que supere a compreensão dicotomizada e essencializada do conceito, ressaltando o caráter dinâmico, multidimensional e relacional da constituição dos sujeitos na interface com as instituições, as culturas e a sociedade (HALL, 1999; MORIN, 2002; CASTELLS, 2013).

Nesse contexto, a relação do sujeito com a religião passa também por transformações. As instituições religiosas da contemporaneidade perdem sua centralidade na constituição de uma estrutura de plausibilidade do real e, em seu lugar, é possível identificar o que vem sendo denominado desregulação institucional, em um movimento no qual o sujeito ganha autonomia para compor sua identidade religiosa, a partir de bricolagens de crenças e diferentes formas de se relacionar com as Igrejas (HERVIEU-LÉGER, 2015; CAMURÇA, 2003). Não obstante, diante da instabilidade das estruturas sociais, políticas e culturais, resultante de ausências no campo da educação formal, da empregabilidade no mercado de trabalho e da confiança no universo político e na atuação do Estado, a religião continua a ser um elemento relevante na constituição da subjetividade. Desse modo, é possível afirmar que a religião tem sido valorizada pelos jovens, ainda que haja indícios de novos modelos de pertencimento e vínculo, não sendo possível apontar para um indiferentismo religioso por parte da juventude, mesmo para aqueles que se denominam sem religião (NOVAES, 2012, 2004b; FERNANDES, 2013).

Se na esfera das religiões o sujeito assume certo protagonismo na constituição de sua identidade religiosa, movimento semelhante ocorre quando nos remetemos à dimensão da política. Partindo de uma perspectiva de política 
atrelada à institucionalidade do Estado e aos partidos políticos, alguns autores apontam para uma apatia e distanciamento por parte dos jovens, identificando uma desenergização da política, resultado da ineficiência e da imoralidade que vem permeando o campo político. No entanto, entendendo a dimensão política a partir de uma abordagem mais ampla, é possível observar o surgimento de novas estratégias de participação e engajamento dos jovens - conselhos de juventude, coletivos juvenis, redes sociais, fóruns, etc. - além de novas pautas, relacionadas tanto a questões universais (consciência planetária) quanto ao cotidiano da juventude, tais como o mundo do trabalho, o lazer, a ação solidária, a violência, a sexualidade (BOGHOSSIAN; MINAYO, 2009; CASTRO, 2015; FERNANDES, 2007). A renovação, em parte, tem vindo da indignação moral da juventude, que funciona como provedora de energia, apontando para novas possibilidades de ação (RIBEIRO, 2004). A este respeito, destaca-se que as manifestações e as pautas reivindicatórias da contemporaneidade são marcadamente parciais, temporárias e imediatas, o que as torna mais emocionais e pragmáticas e menos ideológicas do que o eram há algumas décadas (CASTRO, 2008; DUBAR, 2006).

Não apenas no Brasil, mas também na América Latina, as ações e políticas voltadas para a juventude vêm sendo apresentadas como estratégicas para o desenvolvimento e a superação de desigualdades, tendo em vista os desafios postos pela contemporaneidade. O protagonismo dos jovens, seu engajamento social e político, o fortalecimento dos grupos e organizações juvenis, bem como o atendimento de demandas específicas da juventude têm sido debatidos e colocados em destaque nas diferentes esferas de diversos países. Desse modo, a juventude tem sido vista em seu potencial de transformação social, na medida em que, fortalecidas suas possibilidades de engajamento e participação política, suas demandas podem inclusive suscitar pressões por mudanças junto ao poder público e à sociedade (PNUD, 2014; FREITAS, 2004). Em particular no Brasil, os jovens têm, nos últimos anos, assumido protagonismo em uma série de manifestações sociopolíticas - nas ruas, nas redes sociais e na ocupação de instituições públicas -, em protestos contra a corrupção, a má gestão de recursos públicos e a retirada de 
direitos garantidos pela legislação (MAYORGA; CASTRO; PRADO, 2012; MAYORGA, 2017).

É nesse movimento que entendemos que a vivência e as aprendizagens promovidas pelo Ensino Superior podem contribuir com a formação dos jovens. Em que pesem as contradições e as crises pelas quais vêm passando esta instituição é responsabilidade da Universidade constituir-se como espaço público de produção de conhecimento, discussão crítica, tomada de consciência e engajamento sociopolítico (SANTOS, 2011; SEVERINO, 2009; LANDINELLI, 2009). Nesse sentido, a formação em nível superior certamente promove modificações nas concepções dos jovens, podendo se constituir como um elemento relevante na constituição de suas identidades.

No contexto de tais discussões, portanto, cabe indagar acerca da constituição identitária dos jovens na interface com as dimensões política e religiosa, buscando ainda analisar, a partir da própria compreensão dos sujeitos, as possíveis influências exercidas pela vivência na Universidade. É este o objetivo ao qual nos propomos no presente texto.

\section{Delineando a investigação}

Os dados foram coletados entre os meses de agosto e setembro de 2016, por meio de survey online composto por questões relacionadas ao perfil do jovem e suas compreensões acerca da política e da religião. No momento de aplicação do questionário, o país e o estado do Paraná passavam por um momento de grande instabilidade política, com uma série de eventos e manifestações relacionadas ao impeachment da Presidente Dilma Rousseff, à corrupção e má utilização de recursos públicos, ao corte de recursos para as Instituições de Ensino Superior públicas do Paraná e, ainda, na emergência de um movimento de ocupação de escolas da Educação Básica e de Universidades por todo o Brasil. Esses elementos, mais do que um simples cenário, devem ser compreendidos como constituintes das próprias compreensões e práticas manifestadas pelos participantes da pesquisa, 
tendo em vista, inclusive, o protagonismo que a juventude assumiu em todo esse processo.

Participaram da investigação 203 jovens estudantes da Universidade Estadual do Paraná (Unespar), com idade até 29 anos $^{1}$ (sendo mais de 80\% da amostra com até 24 anos), pertencentes aos cursos de licenciatura da área de Ciências Humanas, assim distribuídos: Filosofia (14 jovens), Geografia (37 jovens), História (42 jovens) e Pedagogia (110 jovens)². A interpretação dos resultados foi realizada a partir do cruzamento dos dados das questões abertas e fechadas, tendo sido ainda construídas categorias de análise que permitissem uma sistematização das respostas dos participantes.

A Unespar3 é uma instituição multicampi e possui unidades em diversas regiões do Paraná, atendendo majoritariamente a estudantes oriundos das escolas públicas - nas quais 91,1\% dos participantes da pesquisa cursaram toda a Educação Básica - e que, em grande parte, representam a primeira geração de suas famílias a ingressarem no Ensino Superior (MEZZOMO; PÁTARO, 2015). A esse respeito, apenas $12,3 \%$ das mães e $4,4 \%$ dos pais dos participantes possuem o Ensino Superior, ao passo que 40,4\% e 45,8, respectivamente, não concluíram o Ensino Fundamental.

Ainda quanto ao perfil dos estudantes, 151 (74,4\%) são do sexo feminino e 52 (25,6\%) do sexo masculino, sendo que 38,4\% possuem renda familiar de até 2 salários mínimos, e 45,3\% entre 2 e 5 salários mínimos. Quanto ao interesse em se

\footnotetext{
${ }^{1} \mathrm{O}$ critério etário utilizado para delimitar a juventude tem abrangido a idade dos 15 aos 29 anos, conforme classificação adotada por órgãos como a Organização das Nações Unidas (ONU) e pelo Estatuto da Juventude (Lei 12.852/2013). Embora neste trabalho seja adotada tal delimitação, compreendemos que o critério etário deve estar associado a outros elementos socioculturais fundamentais na constituição das identidades juvenis.

${ }^{2} \mathrm{O}$ questionário foi aplicado a todos os estudantes matriculados nos terceiros anos dos cursos mencionados. Os dados analisados compreendem a totalidade dos participantes que responderam a todas as questões do instrumento, e que faziam parte do recorte etário considerado na pesquisa. Foram observados os princípios éticos de pesquisa com seres humanos, tendo os jovens participado voluntariamente da investigação.

${ }^{3}$ A Unespar possui mais de 12 mil estudantes, matriculados em 68 cursos de Graduação e 4 Programas de Pós-Graduação Stricto Sensu. É constituída por 7 campus localizados nos municípios de Apucarana, Campo Mourão, Curitiba, Paranaguá, Paranavaí e União da Vitória, abrangendo diferentes regiões do estado. A constituição recente dessa universidade, credenciada em dezembro de 2013, deuse a partir da integração de faculdades estaduais isoladas, guardando, portanto, uma diversidade de experiências da vivência universitária - ligadas ao processo histórico, à instalação e expansão dos cursos, às formas de ingresso, às compreensões acerca do ensino, da pesquisa e da extensão em cada um dos campi.
}

Horizonte, Belo Horizonte, v. 16, n. 50, p. 812-844, maio/ago. 2018 - ISSN 2175-5841 
engajar em alguma causa social, humanitária ou política, 44,8\% dos jovens manifestam discordância, enquanto que $36,4 \%$ expressam o desejo de tal engajamento. Já quanto ao pertencimento religioso, a Tabela 1 apresenta a distribuição dos participantes:

Tabela 1: Pertencimento religioso dos participantes 4

\begin{tabular}{lcc}
\hline Pertencimento religioso & Quantidade & Porcentagem \\
\hline Igreja Católica Apostólica Romana & 110 & 54,2 \\
\hline Evangélico & 43 & 21,2 \\
\hline Acredito em Deus, mas não tenho religião & 24 & 11,8 \\
\hline Ateu, não acredito em Deus & 9 & 4,4 \\
\hline Espírita & 5 & 2,5 \\
\hline Outros & 12 & 5,9 \\
\hline Total & $\mathbf{2 0 3}$ & $\mathbf{1 0 0 , 0}$ \\
\hline
\end{tabular}

Fonte: Dados da pesquisa.

Em síntese, os jovens da pesquisa são em sua maioria do sexo feminino, católicos, oriundos de famílias com baixa escolarização e de camadas populares, expressando uma posição ambígua em relação ao interesse pelo engajamento político e social.

Para o presente trabalho, enfatizamos, em nossas discussões, as compreensões acerca da religião e da participação política e social de jovens universitários vinculados aos três maiores grupos de nossa amostra, tendo em vista o pertencimento religioso: católicos $(54,2 \%)$, evangélicos $(21,2 \%)$ e sem religião (11,8\%, sendo jovens que acreditam em Deus, mas não possuem religião).

\footnotetext{
${ }^{4}$ Foram agrupadas no pertencimento evangélico 17 denominações religiosas, distribuídas da seguinte forma, observando a ordem decrescente no quantitativo de participantes: Igreja Evangélica Batista (10); Igreja Congregação Cristã do Brasil (8); Igreja Assembleia de Deus (7); Igreja do Evangelho Quadrangular (3); Igreja Cristã Maranata (2); Igreja Adventista do Sétimo Dia (2); Assembleia de Deus Renovada (1); Comunidade Evangélica Internacional Aliança com Deus (1); Comunidade Evangélica Monte Sinai (1); Igreja Evangélica do Avivamento Bíblico (1); Igreja Evangélica Presbiteriana (1); Igreja Missionária Unida do Brasil (1); Igreja Mundial do Poder de Deus (1); Igreja O Brasil para Cristo (1); Igreja Palavras que Curam (1); Igreja Pentecostal de Jesus Fonte de Vida Eterna (1); Igreja Unindo Gerações (1).
}

Horizonte, Belo Horizonte, v. 16, n. 50, p. 812-844, maio/ago. 2018 - ISSN 2175-5841 


\section{Religião, política e a vivência na Universidade: a perspectiva dos jovens}

Embora haja similaridades nas compreensões entre os três grupos de jovens universitários analisados, é possível identificar diferenças e especificidades nas representações, formas de engajamento e significados atribuídos à religião, à política, à participação social e à vivência universitária. O grau de confiança dos jovens nas diferentes instituições evidencia tal constatação (Gráfico 1), sendo possível verificar que a instituição na qual depositam maior confiança é a Universidade, o que é semelhante nos três grupos considerados. Já o governo e os políticos são as instituições com menor credibilidade, embora dentre os evangélicos seja possível verificar uma ligeira diferença no que diz respeito à confiança no governo. As organizações religiosas são consideradas de modo diferenciado entre os três grupos, sendo os jovens sem religião os que atribuem menor crédito às mesmas.

Gráfico 1: Grau de confiança dos jovens universitários com relação às instituições

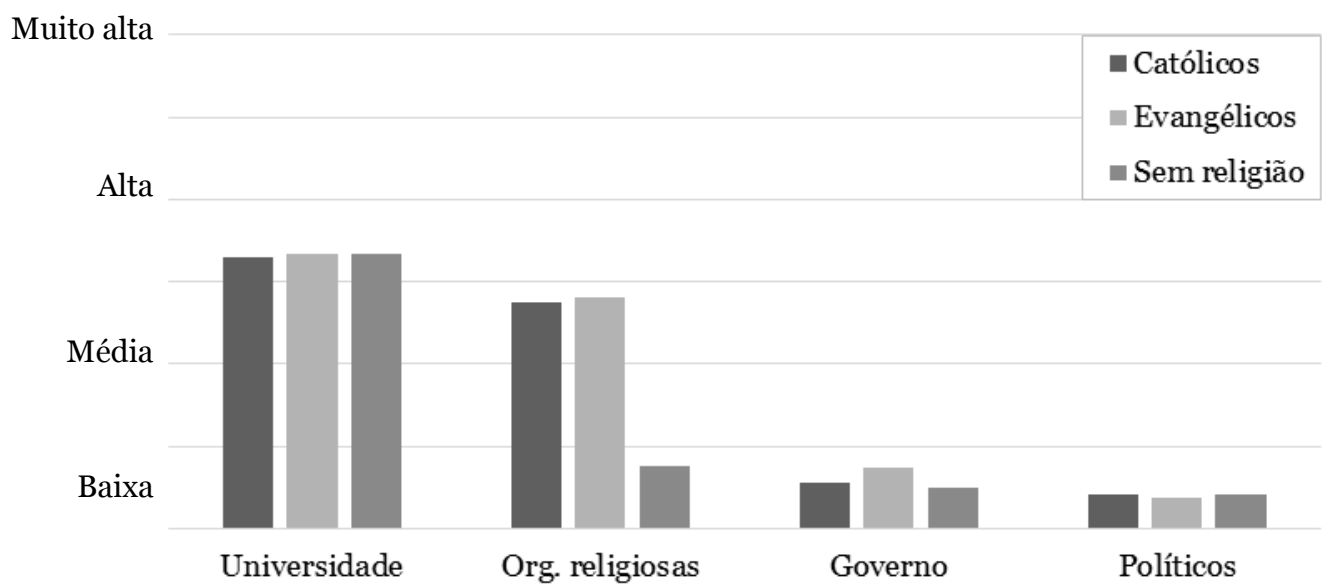

Fonte: Dados da pesquisa. 
A Tabela 2 apresenta o índice de concordância dos jovens dos diferentes grupos quanto a assertivas relacionadas à religião e à política. Os participantes católicos e evangélicos reconhecem que a religião é importante tanto para a própria formação quanto para o país. A este respeito, destaca-se o índice de concordância manifestado pelos evangélicos (86\%) acerca das contribuições da religião à formação humana. Por outro lado, os jovens sem religião discordam de ambas as afirmações (40\% e 26\%, respectivamente).

Tabela 2: Índice de concordância dos jovens universitários quanto a temáticas relacionadas à religião e à política

\begin{tabular}{llcc}
\hline \multicolumn{1}{c}{ Assertiva } & \multicolumn{2}{c}{ Índice de concordância (\%) } \\
\cline { 2 - 4 } & Católicos & $\begin{array}{c}\text { Evangélic } \\
\text { os }\end{array}$ & $\begin{array}{c}\text { Sem } \\
\text { religião }\end{array}$ \\
\hline $\begin{array}{l}\text { 1) A vivência junto à religião contribuiu para minha } \\
\text { formação humana }\end{array}$ & 65 & 86 & 40 \\
\hline 2) A religião é importante para o país & 62 & 66 & 26 \\
\hline $\begin{array}{l}\text { 3) O curso que escolhi tem contribuído para modificar } \\
\text { minhas concepções religiosas }\end{array}$ & 27 & 13 & 43 \\
\hline 4) Os partidos políticos são importantes para o país & 50 & 47 & 46 \\
\hline $\begin{array}{l}\text { 5) O curso que escolhi tem contribuído para modificar } \\
\text { minhas concepções políticas }\end{array}$ & 76 & 73 & 81 \\
\hline 6) A religião e a política devem atuar juntas para resolver & 41 & 34 & 23 \\
problemas sociais & & & \\
\hline 7) Concordo com as orientações e posições da minha Igreja & 42 & 64 & 8 \\
em questões políticas & & & \\
\hline 8) Acredito que a Igreja deve indicar os candidatos que & 7 & 8 & 1 \\
estão mais preparados para ocupar os cargos políticos & & & \\
\hline
\end{tabular}

Fonte: Dados da pesquisa.

Horizonte, Belo Horizonte, v. 16, n. 50, p. 812-844, maio/ago. 2018 - ISSN 2175-5841 
Outro dado relevante refere-se às modificações que o curso de Graduação vem exercendo nas concepções religiosas dos jovens. Em todos os grupos, o índice de concordância encontra-se abaixo dos 50\%, embora seja possível identificar variações entre os três, sobretudo no comparativo entre os sem religião (43\%) e os evangélicos (13\%). Em contraponto, quando se tratam das mudanças nas concepções políticas promovidas pelo curso, o índice de concordância nos três grupos fica acima dos 70\%, expressando que a vivência universitária, na percepção dos jovens, incide mais sobre as concepções políticas do que sobre as religiosas.

No caso das afirmações que buscam ressaltar articulações entre as dimensões da religião e da política (Tabela 2, itens 6 a 8), os participantes manifestam discordância, que parece reforçar o discurso moderno de separação entre as esferas privada e pública. Esta constatação, contudo, é menos evidente no grupo dos evangélicos, cujo grau de concordância com as posições da Igreja em questões políticas atinge 64\%. Este dado, por outro lado, contrasta com a afirmação de que a instituição religiosa deve indicar os candidatos a cargos políticos, cujo índice nesse mesmo grupo cai para 8\%, ficando próxima à avaliação feita pelos jovens católicos.

Quanto à participação dos jovens em atividades sociais e políticas (Tabela 3 e Gráfico 2), é possível verificar que os três grupos possuem perfis e tipos de envolvimento diferenciados. Embora no comparativo entre os dois grupos religiosos seja possível verificar certa semelhança, vale destacar que o engajamento em organizações estudantis entre os jovens católicos (18,2\%) é mais acentuado do que entre os evangélicos (2,3\%). Por outro lado, a participação dos evangélicos em grupos vinculados à Igreja é bem mais expressiva do que entre os católicos $(55,8 \%$ e 20,9\%, respectivamente). 
Tabela 3: Participação dos jovens universitários em atividades sociais e políticas

\begin{tabular}{lccc}
\hline Atividades & Católicos & Evangélicos & $\begin{array}{c}\text { Sem } \\
\text { religião }\end{array}$ \\
\hline $\begin{array}{l}\text { Organizações estudantis ou instâncias representativas } \\
\text { na Universidade }\end{array}$ & 18,2 & 2,3 & 20,8 \\
\hline Mobilizações e ações organizadas via internet & 16,4 & 14,0 & 37,5 \\
\hline Debate via rede social & 17,2 & 9,3 & 33,3 \\
\hline Partidos políticos & 6,4 & 4,7 & 12,5 \\
\hline Grupos vinculados a Igrejas & 20,9 & 55,8 & 4,2 \\
\hline Campanhas solidárias & 25,5 & 18,6 & 16,7 \\
\hline Visitas a instituições caritativas & 10,0 & 14,0 & 16,7 \\
\hline Greves por melhores condições de trabalho e salário & 11,8 & 9,3 & 29,2 \\
\hline Manifestações pela ética na política & 6,4 & 7,0 & 25,0 \\
\hline Gênero & 11,8 & 7,0 & 25,0 \\
\hline
\end{tabular}

Fonte: Dados da pesquisa.

Gráfico 2: Participação dos jovens universitários em atividades sociais e políticas

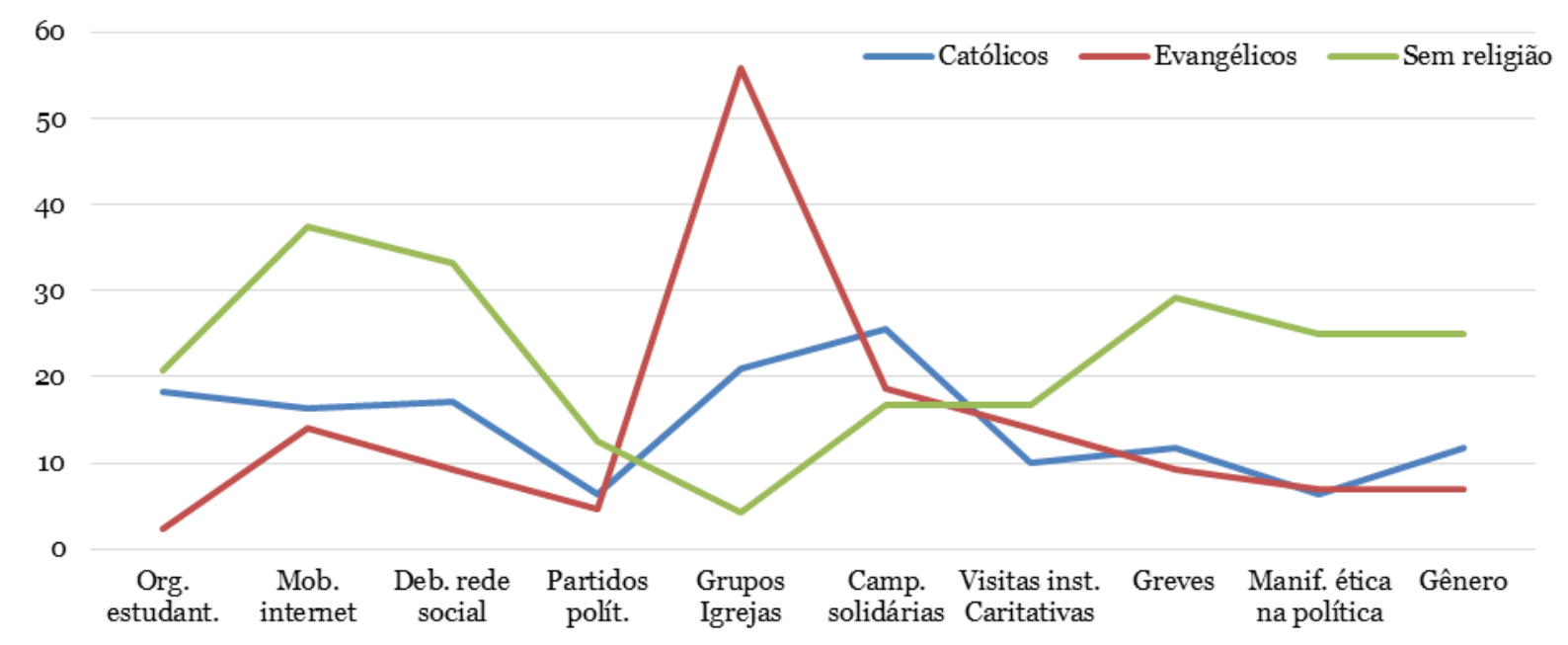

Fonte: Dados da pesquisa. 
Especificamente quanto ao grupo dos sem religião, é possível perceber um maior engajamento dos jovens em quase todas as ações listadas na Tabela 3 e Gráfico 2 - com exceção dos grupos vinculados a Igrejas e de campanhas solidárias. Cabe destaque para a grande participação desses jovens em mobilizações via internet e nas redes sociais, assim como em movimentos grevistas. A respeito deste último, vale lembrar o momento de conflitos travados entre o governo do estado do Paraná e as universidades públicas nos anos de 2015 e 2016, com intensa participação não apenas dos servidores, mas também dos estudantes.

As questões apresentadas na sequência tiveram como objetivo identificar de que modo os jovens universitários percebem as influências do curso de Graduação em suas compreensões sobre política e religião. O Quadro 1, a seguir, apresenta as categorias de análise elaboradas a partir das respostas 5 de todos os jovens participantes da pesquisa - totalizando 203 estudantes. Já os gráficos do Quadro 2 trazem a distribuição das categorias considerando os jovens dos 3 grupos analisados: católicos, evangélicos e sem religião.

Quadro 1: Categorias de análise - Influências do curso de Graduação na compreensão acerca da religião e outras formas de crença

\begin{tabular}{|c|c|c|c|c|}
\hline CATEGORIA & DESCRIÇÃO & EXEMPLO & $\Sigma$ & \% \\
\hline $\begin{array}{c}\text { Pluralidade e } \\
\text { respeito }\end{array}$ & $\begin{array}{c}\text { Compreensão da alteridade, } \\
\text { da diversidade religiosa e } \\
\text { necessidade do respeito às } \\
\text { diferentes formas de crença }\end{array}$ & $\begin{array}{c}\text { "Hoje tenho mais respeito a todas } \\
\text { religiões, pois acredito que no mundo há } \\
\text { povos, raças e culturas que devem ser } \\
\text { mantidas e respeitadas." (Evangélica, 22 } \\
\text { anos, Fem.) }\end{array}$ & $\mathbf{6 7}$ & 33,0 \\
\hline $\begin{array}{c}\text { Sem } \\
\text { mudanças }\end{array}$ & $\begin{array}{c}\text { Não houve influências do } \\
\text { curso de Graduação }\end{array}$ & $\begin{array}{c}\text { Não houve nenhuma mudança." } \\
\text { (Católica, 20 anos, Fem.) }\end{array}$ & $\mathbf{4 2}$ & $\mathbf{2 0 , 7}$ \\
\hline $\begin{array}{c}\text { Enfraqueci- } \\
\text { mento da } \\
\text { verdade } \\
\text { religiosa }\end{array}$ & $\begin{array}{c}\text { Possibilitou conhecimentos } \\
\text { que levaram ao } \\
\text { enfraquecimento da } \\
\text { verdade religiosa. } \\
\text { Composto por 4 } \\
\text { subcategorias: }\end{array}$ & & $\mathbf{4 0}$ & $\mathbf{1 9 , 7}$ \\
\hline
\end{tabular}

\footnotetext{
${ }^{5}$ As respostas dos jovens universitários apresentam diferentes compreensões acerca da influência do curso de Graduação nas concepções sobre religião e política. Para a tabulação dos dados de cada uma dessas questões, foram construídas categorias e subcategorias de análise a partir da leitura das respostas dos participantes, sendo que cada resposta foi vinculada a uma única categoria. Contudo - e dada a complexidade do pensamento humano, bem como das temáticas investigadas -, é válido ressaltar que, em alguns casos, os posicionamentos dos estudantes expressam elementos que podem vir a se articular a outras categorias definidas na pesquisa.
}

Horizonte, Belo Horizonte, v. 16, n. 50, p. 812-844, maio/ago. 2018 - ISSN 2175-5841 


\begin{tabular}{|c|c|c|c|c|}
\hline CATEGORIA & DESCRIÇÃO & EXEMPLO & $\bar{\Sigma}$ & $\%$ \\
\hline $\begin{array}{l}\text { Práticas } \\
\text { negativas } \\
\text { e manipu- } \\
\text { lação }\end{array}$ & $\begin{array}{c}\text { Ênfase nas práticas } \\
\text { negativas e na manipulação } \\
\text { por parte da instituição } \\
\text { religiosa }\end{array}$ & $\begin{array}{c}\text { "Sim, a religião é o ópio do povo! } \\
\text { Doutrina e faz as pessoas fecharem os } \\
\text { olhos para os mais diversos problemas } \\
\text { que envolvem a sociedade [...]." (Sem } \\
\text { religião, } 21 \text { anos, Masc.) }\end{array}$ & 19 & 9,3 \\
\hline 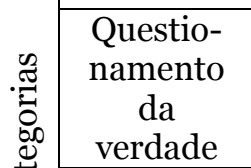 & $\begin{array}{l}\text { Ênfase no questionamento } \\
\text { da verdade pregada pela } \\
\text { religião }\end{array}$ & $\begin{array}{c}\text { "Na religião a mudança foi de perceber } \\
\text { que nem tudo que a igreja diz e prega é } \\
\text { de fato verdade." (Católico, } 20 \text { anos, } \\
\text { Masc.) }\end{array}$ & 12 & 5,9 \\
\hline $\begin{array}{l}\text { Razão e } \\
\text { conheci- } \\
\text { mento }\end{array}$ & $\begin{array}{l}\text { Ênfase no conhecimento e } \\
\text { pensamento racional } \\
\text { adquirido no curso de } \\
\text { Graduação }\end{array}$ & $\begin{array}{l}\text { “O conhecimento científico só me ajudou } \\
\text { a fortalecer as ideias ateístas que eu já } \\
\text { possuía, me fazendo entender mais sobre } \\
\text { ciência e sobre rejeitar conhecimentos } \\
\text { dogmáticos.”(Ateu, } 20 \text { anos, Masc.) }\end{array}$ & 6 & 3,0 \\
\hline $\begin{array}{l}\text { Perda do } \\
\text { poder da } \\
\text { religião }\end{array}$ & $\begin{array}{c}\text { Ênfase na perda do poder } \\
\text { da religião sobre as pessoas } \\
\text { e a sociedade } \\
\end{array}$ & $\begin{array}{c}\text { "A religião deixou de ter o poder máximo } \\
\text { sobre a sociedade." (Católica, } 22 \text { anos, } \\
\text { Fem.) }\end{array}$ & 3 & 1,5 \\
\hline $\begin{array}{l}\text { Importante } \\
\text { para as } \\
\text { pessoas e a } \\
\text { sociedade }\end{array}$ & $\begin{array}{c}\text { Religião entendida como } \\
\text { um elemento importante } \\
\text { para as pessoas e para a } \\
\text { sociedade } \\
\end{array}$ & $\begin{array}{l}\text { "Antes mesmo de iniciar meu curso já } \\
\text { acreditava em Deus, e até os dias de hoje } \\
\text { essa fé só vem a aumentar." (Evangélica, } \\
27 \text { anos, Fem.) }\end{array}$ & 20 & 9,9 \\
\hline $\begin{array}{l}\text { Melhor } \\
\text { compreensão }\end{array}$ & $\begin{array}{l}\text { Novo entendimento acerca } \\
\text { das questões relacionadas à } \\
\text { religião, dado pelo curso de } \\
\text { Graduação } \\
\end{array}$ & $\begin{array}{c}\text { "Vejo com outros olhos." (Católico, } 28 \\
\text { anos, Masc.) }\end{array}$ & $\mathbf{1 1}$ & 5,4 \\
\hline $\begin{array}{l}\text { Múltiplas } \\
\text { categorias }\end{array}$ & $\begin{array}{l}\text { Compreensão que articula } \\
\text { diferentes dimensões } \\
\text { vinculadas às demais } \\
\text { categorias }\end{array}$ & $\begin{array}{l}\text { "Somente deve ser seguida: se não } \\
\text { promover nenhuma forma de } \\
\text { preconceito, discriminação, discurso de } \\
\text { ódio; se incentivar e despertar no } \\
\text { indivíduo a caridade, o interesse e a } \\
\text { compaixão pelo outro, o se colocar no } \\
\text { lugar do outro, incentivar a paz; não falar } \\
\text { mal de outras religiões. Afinal esses } \\
\text { atributos acima citados são princípios } \\
\text { fundamentais para bem exercer a } \\
\text { religiosidade conscientemente e } \\
\text { racionalmente." (Espírita, } 28 \text { anos, Fem.) }\end{array}$ & 3 & 1,5 \\
\hline $\begin{array}{c}\text { Não sabe/Não } \\
\text { respondeu }\end{array}$ & $\begin{array}{c}\text { Não sabe ou não respondeu } \\
\text { à questão }\end{array}$ & $\begin{array}{c}\text { "Indiferente." (Sem religião, } 19 \text { anos, } \\
\text { Masc.) }\end{array}$ & 7 & 3,4 \\
\hline Outros & $\begin{array}{c}\text { Outros sentidos e } \\
\text { compreensões não } \\
\text { expressos em nenhuma das } \\
\text { categorias anteriores } \\
\end{array}$ & $\begin{array}{l}\text { "Houve alguns cultos, cerimônias } \\
\text { religiosas, mas não participo." (Ateia, } 20 \\
\text { anos, Fem.) }\end{array}$ & 13 & 6,4 \\
\hline \multicolumn{3}{|c|}{ Total } & 203 & 100,0 \\
\hline
\end{tabular}

Fonte: Dados da pesquisa. 
Quadro 2: Distribuição dos participantes católicos, evangélicos e sem religião nas categorias de análise: influências do curso de Graduação na compreensão acerca da religião e outras formas de crença

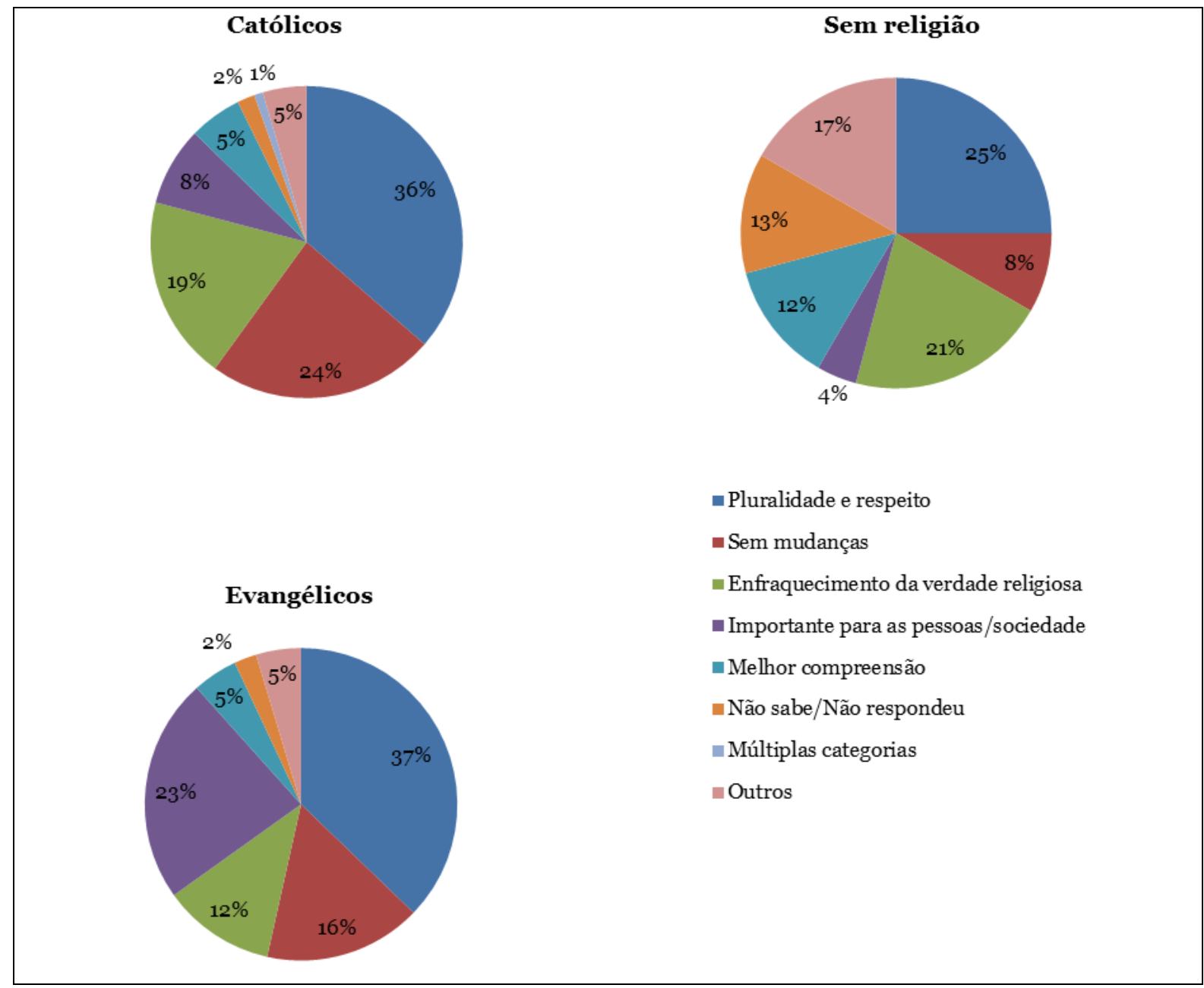

Fonte: Dados da pesquisa.

A organização das compreensões dos jovens universitários em categorias e subcategorias de análise permite sistematizar o modo como os estudantes percebem as influências do curso de Graduação em suas concepções religiosas - e, mais adiante, nas concepções políticas -, sendo possível verificar proximidades e distanciamentos no perfil dos três grupos analisados. As oito categorias construídas expressam, por um lado, a complexidade e a diversidade das compreensões manifestadas pelos participantes e, ao mesmo tempo, algumas recorrências, 
comuns aos jovens católicos, evangélicos e aos sem religião. As respostas trazem tanto a percepção de que o curso de Graduação não incide sobre a concepção religiosa, quanto aquelas que enfatizam as mudanças ocorridas, seja a partir do enfraquecimento da religião, da reafirmação da opção religiosa, de um novo entendimento acerca dessa dimensão, entre outros. Assim, é possível afirmar que as diferentes categorias de análise apresentadas evidenciam os vários significados atribuídos pelos jovens não só às aprendizagens e vivências no curso de Graduação, mas também à religião, à crença e ao pertencimento.

Dentre as categorias de análise construídas, a que agrega um maior número de participantes nos três grupos analisados é a que enfatiza a pluralidade e a importância do respeito às diferentes formas de crença religiosa - representando $36 \%$ dos jovens católicos, 37\% dos evangélicos e 25\% dos sem religião. Os jovens que constroem suas respostas a partir desse raciocínio afirmam que o curso de Graduação permitiu o conhecimento de diferentes culturas, que manifestam diversas compreensões acerca do sagrado, expressando ainda a importância do respeito à opção religiosa de cada um - seja do próprio sujeito ou do outro.

A despeito dessa recorrência, que se configura como uma regularidade nos três grupos, a distribuição dos participantes em outras categorias traz especificidades e distanciamentos no perfil dos jovens. Os universitários católicos, por exemplo, destacam-se por apresentar o maior índice de participantes (24\%) para os quais o curso de Graduação não influenciou nas concepções referentes à religião. Quanto aos evangélicos, vale destacar a menor incidência, dentre os três grupos, daqueles que enfatizam o enfraquecimento da verdade religiosa (12\%), e, ao mesmo tempo, a maior recorrência acerca da importância da religião para a sociedade e as pessoas (23\%). Por fim, dentre os sem religião, 21\% enfatizam um enfraquecimento da verdade religiosa a partir do curso de Graduação - maior índice dentre os três grupos -, enquanto 8\% afirmam não haver mudanças nas concepções acerca da religião, e apenas 4\% entendem a religião como importante representando, nesses casos, os menores índices no comparativo com os católicos e os evangélicos. 


\section{Quadro 3: Categorias de análise - Influências do curso de Graduação na compreensão acerca da política e das formas de participação}

\begin{tabular}{|c|c|c|c|c|c|}
\hline \multicolumn{2}{|c|}{ CATEGORIA } & DESCRIÇĀO & EXEMPLO & $\bar{\Sigma}$ & $\%$ \\
\hline \multicolumn{2}{|c|}{$\begin{array}{l}\text { Descrença } \\
\text { na política }\end{array}$} & $\begin{array}{c}\text { Compreensões que } \\
\text { expressam uma descrença } \\
\text { para com a política. } \\
\text { Composto por } 2 \\
\text { subcategorias: } \\
\end{array}$ & & 59 & 29,1 \\
\hline \multirow{2}{*}{ 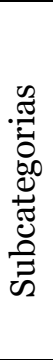 } & $\begin{array}{l}\text { Pessi- } \\
\text { mismo }\end{array}$ & $\begin{array}{l}\text { Ênfase no pessimismo diante } \\
\text { da atuação dos políticos, } \\
\text { partidos e grupos }\end{array}$ & $\begin{array}{l}\text { "Os políticos não querem de forma } \\
\text { alguma que a sociedade acorde e veja que } \\
\text { eles estão apenas roubando de nós." } \\
\text { (Evangélica, } 22 \text { anos, Fem.) }\end{array}$ & 34 & 16,8 \\
\hline & $\begin{array}{l}\text { Manipu- } \\
\text { lação e } \\
\text { jogos de } \\
\text { interess } \\
\text { e }\end{array}$ & $\begin{array}{l}\text { Ênfase na manipulação e } \\
\text { jogos de interesse que se } \\
\text { fazem presentes na política }\end{array}$ & $\begin{array}{l}\text { “[...] o poder de manipulação da política, } \\
\text { compreender seu funcionamento e suas } \\
\text { origens [...]." (Católica, } 21 \text { anos, Fem.) }\end{array}$ & 25 & 12,3 \\
\hline \multicolumn{2}{|c|}{$\begin{array}{c}\text { Formas de } \\
\text { engajamento }\end{array}$} & $\begin{array}{l}\text { Política entendida como } \\
\text { resultado do engajamento } \\
\text { das pessoas e grupos. } \\
\text { Composto por } 2 \\
\text { subcategorias: }\end{array}$ & & 55 & 27,1 \\
\hline \multirow{2}{*}{ 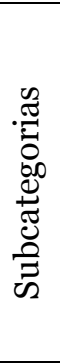 } & $\begin{array}{l}\text { Partici- } \\
\text { pação }\end{array}$ & $\begin{array}{c}\text { Ênfase em diferentes formas } \\
\text { de participação na vida } \\
\text { política }\end{array}$ & $\begin{array}{l}\text { "Me encorajou mais ao engajamento } \\
\text { político, as greves, as manifestações nas } \\
\text { ruas e pressões populares, que tem } \\
\text { grande responsabilidade em mudar o } \\
\text { curso da história." (Ateu, } 27 \text { anos, Masc.) }\end{array}$ & 49 & 24,1 \\
\hline & $\begin{array}{l}\text { Demo- } \\
\text { cracia }\end{array}$ & $\begin{array}{l}\text { Ênfase na democracia como } \\
\text { forma de governo a ser } \\
\text { consolidada }\end{array}$ & $\begin{array}{l}\text { "É preciso que se trabalhe com a } \\
\text { democracia, fazendo de todos } \\
\text { participantes de um mesmo processo." } \\
\text { (Sem religião, } 21 \text { anos, Masc.) } \\
\end{array}$ & 6 & 3,0 \\
\hline \multicolumn{2}{|c|}{$\begin{array}{l}\text { Conhecimen } \\
\text { to da política }\end{array}$} & $\begin{array}{c}\text { Conhecimento sobre o } \\
\text { mundo da política obtido a } \\
\text { partir do curso de } \\
\text { Graduação. Composto por } 2 \\
\text { subcategorias: } \\
\end{array}$ & & 50 & 24,6 \\
\hline \multirow{2}{*}{ 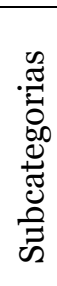 } & $\begin{array}{l}\text { Melhor } \\
\text { com- } \\
\text { preensã } \\
\text { o }\end{array}$ & $\begin{array}{c}\text { Ênfase a um novo } \\
\text { entendimento da política } \\
\text { proporcionado pelo curso de } \\
\text { Graduação }\end{array}$ & $\begin{array}{c}\text { “Sim, aprendi mais sobre a política } \\
\text { existente do país.” (Evangélica, } 24 \text { anos, } \\
\text { Fem.) }\end{array}$ & 26 & 12,8 \\
\hline & $\begin{array}{l}\text { Posicio- } \\
\text { nament } \\
\text { o crítico }\end{array}$ & $\begin{array}{l}\text { Ênfase na postura crítica e } \\
\text { conhecimentos teóricos } \\
\text { adquiridos ao longo do curso }\end{array}$ & $\begin{array}{l}\text { "Ter mais criticidade quanto a estrutura } \\
\text { da política no país." (Católico, } 22 \text { anos, } \\
\text { Masc.) }\end{array}$ & 24 & 11,8 \\
\hline \multicolumn{2}{|c|}{$\begin{array}{c}\text { Sem } \\
\text { mudanças }\end{array}$} & $\begin{array}{l}\text { Não houve influências do } \\
\text { curso de Graduação }\end{array}$ & $\begin{array}{l}\text { "Não creio que a graduação traga formas } \\
\text { de influenciar politicamente os } \\
\text { graduandos." (Atéia, } 22 \text { anos, Fem.) }\end{array}$ & 7 & 3,4 \\
\hline \multicolumn{2}{|c|}{$\begin{array}{l}\text { Política e } \\
\text { Sociedade }\end{array}$} & $\begin{array}{l}\text { Política entendida como } \\
\text { elemento que constitui a } \\
\text { sociedade e o cotidiano }\end{array}$ & $\begin{array}{c}\text { "Gostando ou não, a política faz parte de } \\
\text { nosso cotidiano, precisamos ter mais } \\
\text { interesse por ela de modo que possamos } \\
\text { modificá-la nos aspectos que nos } \\
\text { desagradam." (Sem religião, } 24 \text { anos, } \\
\text { Fem.) }\end{array}$ & 7 & 3,4 \\
\hline
\end{tabular}

Horizonte, Belo Horizonte, v. 16, n. 50, p. 812-844, maio/ago. 2018 - ISSN 2175-5841 


\begin{tabular}{|c|c|c|c|c|}
\hline CATEGORIA & DESCRIÇÃO & EXEMPLO & $\mathbf{\%}$ \\
\hline $\begin{array}{c}\text { Múltiplas } \\
\text { categorias }\end{array}$ & $\begin{array}{c}\text { Compreensão que articula } \\
\text { diferentes dimensões } \\
\text { vinculadas às demais } \\
\text { categorias }\end{array}$ & $\begin{array}{c}\text { "A política em dias atuais me deprime } \\
\text { profundamente. O Brasil, com a força } \\
\text { que tem diante dos outros países, deveria } \\
\text { ter uma democracia no seu sentido } \\
\text { pleno, o que não há, diante dos fatos que } \\
\text { ocorreram nos últimos dias e meses. A } \\
\text { democracia que os gregos propuseram, o } \\
\text { Brasil não conseguiu implantar, } \\
\text { infelizmente." (Católico, 20 anos, Masc.) }\end{array}$ & $\mathbf{5}$ & 2,6 \\
\hline $\begin{array}{c}\text { Não } \\
\text { sabe/Não } \\
\text { respondeu }\end{array}$ & $\begin{array}{c}\text { Não sabe ou não respondeu àn } \\
\text { questão }\end{array}$ & $\begin{array}{c}\text { "Não sei." (Ateia, 21 anos, Fem.) } \\
\text { Outros sentidos e }\end{array}$ & 7 & 3,4 \\
\hline Outros & $\begin{array}{c}\text { compreensões não expressos } \\
\text { em nenhuma das categorias } \\
\text { anteriores }\end{array}$ & $\begin{array}{c}\text { "Política é um debate, onde pode ser } \\
\text { tratado diversos assuntos." (Católica, 20 } \\
\text { anos, Fem.) }\end{array}$ & $\mathbf{1 3}$ & 6,4 \\
\hline \multicolumn{2}{|c|}{ TOTAL } & 203 & 100,0 \\
\hline
\end{tabular}

Fonte: Dados da pesquisa.

Quadro 4: Distribuição dos participantes católicos, evangélicos e sem religião nas influências do curso de Graduação: compreensão da política e participação
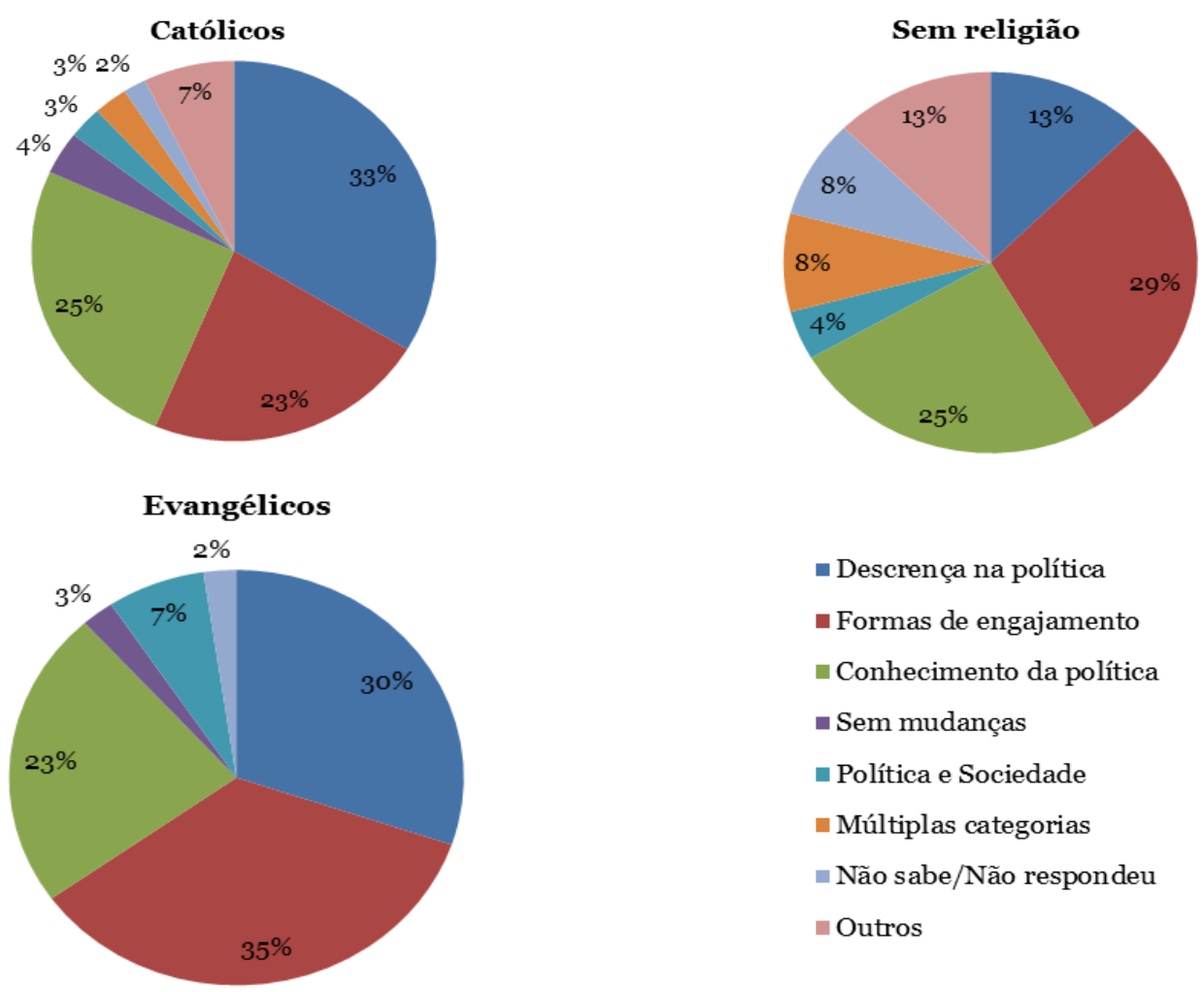

Fonte: Dados da pesquisa.

Horizonte, Belo Horizonte, v. 16, n. 50, p. 812-844, maio/ago. 2018 - ISSN 2175-5841 
O mesmo exercício de sistematização para a construção de categorias de análise foi realizado em relação às influências do curso de Graduação nas concepções acerca da política, a partir da percepção dos jovens universitários. Foram identificadas 8 categorias, com base nas respostas dos estudantes, que abrangem compreensões que enfatizam, por exemplo, a descrença na política, a importância do engajamento juvenil, a ampliação do conhecimento proporcionado pelo curso de Graduação, dentre outros.

Com base na distribuição dos participantes nas categorias de análise, podemos verificar os diversos significados atribuídos à política, às formas de participação e às influências proporcionadas pela vivência universitária, que se fazem presentes nos diferentes perfis dos três grupos investigados. No caso dos jovens sem religião, por exemplo, ganha destaque o quantitativo de participantes que manifestam descrença pela política, representando o menor índice dentre os grupos analisados - 13\%, em contraposição aos 30\% de evangélicos e 33\% de católicos. Já dentre os estudantes evangélicos, foi expressiva a parcela de jovens (35\%) que enfatizam a importância do curso de Graduação na compreensão das formas de engajamento na vida política. Uma categoria igualmente recorrente nos três grupos é a que expressa que o curso de Graduação trouxe aos jovens um maior conhecimento sobre a política e as formas de participação, correspondendo a $23 \%$ dos evangélicos e 25\% dos católicos e também dos sem religião. Cabe ainda ressaltar que, diferentemente do que ocorre nas compreensões acerca da religião, poucos foram os jovens que afirmaram não ter havido mudanças em suas concepções políticas a partir das aprendizagens e vivências na Universidade.

\section{Católicos, evangélicos e sem religião: analisando as compreensões dos jovens universitários}

A partir dos dados apresentados, podemos identificar determinadas tendências no perfil e nas compreensões de cada um dos três grupos investigados. Os jovens católicos compõem a maior parte de nossa amostra, totalizando 110 universitários. Destes, 106 herdaram a religião de suas famílias, manifestando que 
tal pertencimento ocorre desde o nascimento. Esse quantitativo representa 96,4\% dos católicos participantes, e contrasta com os jovens dos demais grupos que declaram essa mesma condição, já que apenas 15 (34,9\%) dentre os evangélicos e 2 $(8,3 \%)$ dos sem religião afirmam tal pertencimento desde que nasceram. Esse dado é coerente com a realidade brasileira, considerando que a religião católica foi majoritária e hegemônica no país até o final do século XX (SANCHIS, 1994; NOVAES, 2004a), quando outros grupos religiosos passaram a ganhar visibilidade, não apenas pelo quantitativo crescente na população - como no caso das religiões evangélicas -, mas também pelo reconhecimento público que passam a reivindicar - em um processo também denominado minoritização (BURITY, 2016, 2017).

O fato de assumirem o pertencimento religioso, no entanto, não significa uma frequência assídua à instituição religiosa. Nesse sentido, apenas 35,5\% dos jovens católicos declaram participar diária ou semanalmente em atividades de sua Igreja, enquanto que, no caso dos evangélicos, o mesmo dado representa mais de 88\%, dinâmica já apontada por outras pesquisas (FERNANDES, 2009; BOHN, 2004; ALMEIDA; MONTERO, 2001; NOVAES, 2001). Quanto à participação em atividades sociais, as que mais se destacam dentre os jovens católicos são os grupos vinculados a Igrejas (20,9\%) e as campanhas solidárias (25\%), reforçando, neste último caso, uma tendência já apontada em outros trabalhos acerca de uma certa afinidade do catolicismo para o envolvimento em atividades sociais (GIUMBELLI, 1993; PAIVA, 2003).

Considerando as compreensões quanto às temáticas da política e da religião, suas concepções se aproximam em vários aspectos das dos evangélicos, como no caso da participação em algumas das atividades sociais e políticas e também na distribuição das categorias referentes às mudanças nas concepções sobre religião e política dadas pelo curso de Graduação (Quadros 2 e 4). Em alguns poucos aspectos, há uma aproximação com o perfil dos jovens sem religião, como no caso da participação em organizações estudantis. Nos demais elementos analisados, expressam em geral um posicionamento intermediário na relação com os grupos 
mencionados (Tabelas 2 e 3). Essa peculiaridade do perfil dos jovens católicos que não se repete dos demais grupos, como veremos adiante - pode estar relacionada a duas dinâmicas próprias desta Igreja no contexto brasileiro. Por um lado, cabe constatar que existe uma pluralidade de práticas e crenças dentro do catolicismo, gerando uma plasticidade e um jeito brasileiro de ser católico (SANCHIS, 1992, 1994; TEIXEIRA, 2005). Por outro lado, parece que a Igreja, desde sua instalação no Brasil Colônia, adotou estratégias para abarcar em sua doutrina e em suas pastorais uma multiplicidade de culturas e outras formas de crença presentes na população, sem gerar rupturas e cismas internas, e passando a conviver com as diversas formas de catolicismo (SOUZA, 2004; BRANDÃO, 2004; BEOZZO, 1995; DUSSEL, 1992). Essa realidade sociorreligiosa ajuda a entender as diferentes tendências apresentadas no perfil dos jovens católicos de nossa amostra, cujo grupo é certamente composto por sujeitos que assumem diferentes formas de crer e pertencer à religião.

A despeito dessa característica, é possível verificar que a importância da crença religiosa, para esses jovens, é afirmada em diferentes momentos. A importância da religião na formação humana e também para o país recebeu um grau de concordância de 65\% e 62\%, respectivamente. No mesmo sentido, os índices de $42 \%$ e 41\%, nessa ordem, foram atribuídos à concordância com as orientações da Igreja em questões políticas e à afirmação de que religião e política devem atuar juntas na resolução dos problemas sociais (Tabela 2). Por fim, a importância da religião na identidade desses jovens é novamente afirmada quando 24\% dos católicos - o maior índice dentre os três grupos - expressam que o curso de Graduação não influenciou sua forma de compreender a religião (Quadro 2). Os trechos a seguir ilustram como esses jovens compreendem que a crença religiosa depende de uma escolha particular e que, por esse motivo, não foi modificada a partir das aprendizagens adquiridas na Universidade:

Já tenho minha concepção de religião e ela não mudou conforme o tempo, apenas só aumenta minha fé e minha certeza que estou na religião certa. (Católica, 21 anos, Fem.).

Horizonte, Belo Horizonte, v. 16, n. 50, p. 812-844, maio/ago. 2018 - ISSN 2175-5841 
Em relação à religião, o curso não modificou e nem acrescentou nada, pois cada um tem a sua escolha e o que realmente importa é valorizá-la e respeitar acima de tudo. (Católica, 23 anos, Fem.).

A presença da religião na identidade é também uma característica relevante no perfil do grupo de evangélicos, sendo ainda mais marcante do que no caso dos católicos. Dentre os jovens evangélicos, $23 \%$ enfatizam a importância da religião para as pessoas e a sociedade, ao serem questionados acerca de suas concepções a partir das vivências na Graduação (Quadro 2). Em termos percentuais, os evangélicos recorrem a essa categoria quase 3 vezes mais do que os católicos (8\%) e 6 vezes mais do que os sem religião (4\%). Os trechos a seguir expressam as compreensões e significados atribuídos pelos jovens evangélicos a essa questão:

A religião [...] é algo que me dá uma base, mas o foco pra mim é Deus, ele é o centro da minha vida, e mesmo que na universidade critiquem isso, nunca deixarei de acreditar no meu Deus, pois é ele que eu amo e me sustenta sempre. (Evangélica, 20 anos, Fem.).

As pessoas estão cada vez mais frias, muitas não acreditam em nada... Com o passar dos anos, percebo que minha fé em Deus é que me faz continuar as batalhas diariamente, pois eu confio nas promessas que Ele tem para minha vida. (Evangélica, 21 anos, Fem.).

Na mesma direção, as assertivas sobre a importância da religião para a formação humana e para o país receberam, no caso dos jovens evangélicos, índices de concordância de $86 \%$ e 66\%, respectivamente. Ainda, o grau de concordância com a afirmação de que o curso de Graduação contribui para a modificação das concepções religiosas é o menor dentre os três grupos investigados, representando apenas $13 \%$, em contraposição aos índices de $27 \%$ no caso dos católicos e $43 \%$ para os sem religião (Tabela 2).

Além da relevância que a crença religiosa assume na identidade desses jovens, dentre os três grupos investigados, os evangélicos são os que apresentam maior grau de concordância (64\%) com as orientações políticas dadas pela Igreja. Não obstante, não é possível afirmar que haja uma completa assimilação de todas as orientações eclesiásticas, na medida em que os jovens discordam veementemente que a instituição religiosa deve indicar os candidatos mais 
preparados para ocupar os cargos políticos (Tabela 2, item 8). Esse é um dado que chama a atenção, pois a literatura vem apontando uma tendência, por parte das Igrejas evangélicas - sobretudo no caso das pentecostais -, para um processo de racionalização e um planejamento de ocupação do espaço público, mais precisamente no campo da política formal, manifestando apoio e/ou lançando candidatos oficiais ao legislativo e executivo (MACHADO; BURITY, 2014; CAMPOS, 2013; RODRIGUES; FUKS, 2015). Além disso, mesmo considerando os múltiplos condicionantes sociais na definição do voto, pesquisas vêm indicando que, entre os evangélicos - especialmente os pentecostais -, há maior probabilidade de que a religião influencie os processos eleitorais (NOVAES, 2004b). Ainda assim, e contrariando as tendências mencionadas, os jovens investigados discordam da indicação de candidatos por parte da Igreja, e parecem manifestar uma compreensão que reforça as especificidades de cada uma das esferas - da política e da religião.

No que tange às atividades sociopolíticas, o grupo dos jovens evangélicos é o que apresenta os menores índices de participação, no comparativo com os demais, à exceção das visitas a instituições caritativas e manifestações pela ética na política - cujos índices se assemelham aos dos católicos -, além da participação em grupos vinculados à Igreja - que no caso dos evangélicos atinge 55,8\%, em contraste com 20,9\% dos católicos e 4,2\% dos sem religião. Esse dado coincide com uma tendência já identificada em outra pesquisa realizada junto a jovens religiosos, na qual a atuação em atividades sociopolíticas mostrou-se mais intensa entre os católicos do que entre os pentecostais (FERNANDES, 2009). Não obstante esse distanciamento dos jovens evangélicos em relação às atividades sociopolíticas, é curioso verificar que, na compreensão dos mesmos estudantes, a instituição religiosa vem incentivando os jovens a participarem de partidos políticos $(16,3 \%)$, greves (14\%) e manifestações pela ética na política (25,6\%).

Se por um lado os índices de participação dos jovens evangélicos são inferiores aos dos demais grupos, por outro lado, ao serem questionados acerca da 
influência do curso de Graduação em suas concepções políticas, é neste grupo religioso que as formas de engajamento político ganham mais destaque (Quadro 4). Assim, dentre os estudantes evangélicos, 35\% afirmam - a exemplo dos relatos a seguir - que a vivência na Universidade contribui para que compreendam a importância da participação na política - categoria que foi mencionada em menor grau dentre os católicos (23\%) e os sem religião (29\%).

No curso, percebemos a importância de se tomar uma posição política e também de participar da aplicação política em nossa sociedade. Como sujeitos críticos que devemos ser, temos a necessidade de buscar nossos direitos políticos e de conhecer um pouco da política de nosso país para que, na hora de reivindicar algo, possamos de fato saber o que estamos buscando. (Evangélica, 20 anos, Fem.).

Deixei daquele discurso de que não se discute política, passei a reconhecer a importância de sermos agentes dos rumos da nossa sociedade. De estarmos presentes em discussões; de que devemos de forma acentuada buscar conhecimento [...]. (Evangélica, 22 anos, Fem.).

A partir da complexidade evidenciada em nossos dados, reafirmamos a importância de se problematizar representações que associam os jovens religiosos - especialmente aqueles vinculados a instituições evangélicas - a um distanciamento da política, à alienação ou mesmo a posicionamentos conservadores (FERNANDES, 2007; BOHN, 2004; ORO, 2003; NOVAES, 2001). Ademais, é preciso também considerar que o próprio olhar para os evangélicos não deve assumi-los como um grupo coeso e homogêneo, tendo em vista não apenas a diversidade de denominações, como também as disputas internas ao campo religioso, bem como os demais fatores - externos à religião - que influenciam nos processos identitários e nas sociabilidades (VITAL DA CUNHA; LOPES; LUI, 2017). Tais perspectivas homogeneizantes e simplificadoras, ao que parece, são insuficientes para a compreensão das influências, articulações e imbricações dos aspectos políticos e religiosos nas identidades juvenis, expressas em suas concepções, práticas e relações.

O terceiro grupo analisado diz respeito aos jovens sem religião, que, em nossa pesquisa, referem-se àqueles que afirmam acreditar em Deus, mas não ter 
religião. Os dados do último Censo do IBGE $^{6}$ confirmam o crescimento dessa categoria no Brasil, que, se em 1970 representava 0,8\% da população, em 2010 chegou a 8,04\%, ou 15,3 milhões de brasileiros (MARIANO, 2013). Convém destacar que, como já vem sinalizando a literatura, os sem religião constituem um grupo heterogêneo em relação às suas crenças e grau de distanciamento e participação em instituições religiosas (RODRIGUES, 2012; FERNANDES, 2013; NOVAES, 2004b), o que, em certa medida, também se refletiu em nossos dados.

Os participantes sem religião expressam um distanciamento para com a instituição religiosa, mas não necessariamente para com a religiosidade, como já vem sendo apontado em outras discussões acerca desse grupo (LUIZ, 2013; BONINI; MEZZOMO; PÁTARO, 2016). Nesse sentido, 54,2\% dos jovens da pesquisa afirmam não acreditar na Igreja. É ainda dos sem religião o menor percentual de participação junto a grupos vinculados a instituições eclesiásticas (4,2\%), bem como os menores índices de concordância com as assertivas acerca da importância da religião para o país (26\%) e de que religião e política deveriam atuar juntas na resolução de problemas sociais (23\%). Ao mesmo tempo, além de acreditarem em Deus (95,8\%) e em Jesus Cristo $(87,5 \%)$, há também uma parcela significativa que concorda que um ser superior dá sentido à própria vida $(58,3 \%)$, o que reforça a presença dos aspectos religiosos na constituição das identidades desses jovens.

No que diz respeito às influências da vivência universitária nas concepções religiosas, é dentre os sem religião que observamos a menor incidência daqueles que afirmam que o curso não promoveu mudanças, categoria que representa apenas 8\% (Quadro 2). Em contraposição, é nesse grupo a maior incidência dos jovens que evidenciam um enfraquecimento da verdade religiosa como resultado das aprendizagens proporcionadas pela Graduação (21\%), compreensão que se faz presente no relato a seguir: “A religião serve para doutrinar pessoas que permitem

\footnotetext{
${ }^{6}$ Cabe destacar que, diferentemente dos dados de nossa pesquisa, o IBGE agrega na categoria sem religião também aqueles que se autoidentificam ateus e agnósticos. De toda forma, se excluirmos estes dois grupos, o percentual indicado pelo Censo passa de $8,04 \%$ para $7,65 \%$.
}

Horizonte, Belo Horizonte, v. 16, n. 50, p. 812-844, maio/ago. 2018 - ISSN 2175-5841 
ou querem se deixar levar por alguém, que utiliza de uma frase bíblica para tentar arguir seus fieis e tê-los nas mãos" (Sem religião, 28 anos, Masc.). Como evidenciado anteriormente, o distanciamento da instituição ressaltado por essa categoria de análise não implica necessariamente na inexistência de crenças religiosas por parte dos jovens. Essa constatação é reforçada pelo seguinte trecho:

A faculdade não alterou minha vivência pessoal com a religião e/ou igreja. Saí dos meios religiosos por questões pessoais. Certamente a faculdade me ajudou a manter uma reflexão comigo mesma quanto aos diversos assuntos, e assim percebi questões divergentes quanto à religião e meus conceitos. (Sem religião, 20 anos, Fem.).

Com relação às influências do curso de Graduação nas concepções políticas, os jovens sem religião são os que expressam menor descrença - categoria mencionada por apenas $13 \%$, enquanto que dentre os católicos e os evangélicos correspondeu a 33\% e 30\%, respectivamente (Quadro 4). Os sem religião são, ainda, os jovens que mais participam de atividades sociopolíticas (Tabela 3) - com exceção da participação em grupos vinculados a Igrejas (4,2\%). A esse respeito, cabe destaque para os percentuais destes jovens que declaram participar de mobilizações e debates em redes sociais (acima dos 30\%), manifestações pela ética na política, movimentos de greve e daqueles vinculados às temáticas de gênero (todos com índices superiores a 25\%). Mesmo no que tange à participação em partidos políticos - instituição formal que, segundo a literatura, tem recebido pouca adesão por parte da juventude (BRENNER, 2014; RIBEIRO, 2004) - os jovens sem religião de nossa pesquisa se destacam, tendo em vista que $12,5 \%$ declaram tal participação, frente a apenas 6,4\% dos católicos e 4,7\% dos evangélicos. Esses dados contrastam com outras pesquisas acerca da participação sociopolítica dos sem religião, nas quais os índices são inferiores ou não apresentam diferenças significativas na relação com jovens religiosos (SIMÕES, 2007; FERNANDES, 2013; BONINI; 2016).

Como podemos verificar, a crença religiosa que caracteriza e demarca cada um dos grupos de nossa investigação - católicos, evangélicos e sem religião parece dimensionar, em grande medida, o perfil dos jovens investigados, inclusive 
no que diz respeito à participação em atividades sociopolíticas. A despeito das especificidades e tendências identificadas, há alguns elementos a serem destacados e que são comuns a todos os participantes, sugerindo que, além do pertencimento e crença religiosa, outros aspectos atuam e subsidiam a constituição identitária desses jovens universitários. É a partir desse entendimento que cabe mencionar, por exemplo, o descrédito atribuído ao governo e aos políticos (Gráfico 1), possivelmente decorrente não apenas dos embates no contexto estadual e federal do Brasil - conforme já mencionado -, mas também das instabilidades e incertezas do cenário contemporâneo (BECK, 2010; BAUMAN, 2001; GIDDENS, 2002). Em contraposição, a Universidade recebe o maior grau de confiança por parte dos jovens. Esse dado é coerente com os resultados de outras pesquisas já realizadas no Brasil e na América Latina, segundo as quais a Universidade é a instituição mais valorizada pelos jovens de diferentes países (PNUD/OIJ, 2013). Contudo, no caso dos participantes de nossa investigação, vale a observação - conforme já mencionado - de que quase 90\% desses jovens constituem a primeira geração de suas famílias a cursarem o Ensino Superior, o que certamente cria em torno da formação universitária uma expectativa ainda maior.

Outro aspecto a ser destacado e que aproxima os três grupos juvenis, referese às influências exercidas pelo curso de Graduação em suas concepções: ao que parece, segundo afirmam os próprios jovens, as compreensões acerca da política são muito mais modificadas pelas vivências na Universidade do que aquelas referentes à religião - vide assertivas 3 e 5 da Tabela 2 e, ainda, o quantitativo de jovens que constroem suas respostas de acordo com a categoria "Sem mudanças" nos Quadros 1 e 3. Nesse sentido, a dimensão da política parece ser mais suscetível a mudanças e ressignificações, enquanto a dimensão religiosa apresenta-se menos permeável e mais arraigada à representação que o jovem tem de si mesmo.

Por fim, ressaltamos que é recorrente, nos três grupos, uma visão relutante quanto à atuação conjunta da religião e da política na resolução de problemas sociais, e um posicionamento radicalmente contrário à participação da Igreja na 
política, mediante a indicação de candidatos (Tabela 2, itens 6 e 8), o que parece reforçar uma representação que distancia a religião - vista como elemento de foro íntimo - da política, ligada primordialmente à esfera pública.

\section{Conclusão}

Ao investigarmos as compreensões de estudantes universitários acerca da religião e da política, buscamos aprofundar nossa análise a partir do perfil de três grupos de jovens: católicos, evangélicos e sem religião. Com base nos dados da pesquisa, pudemos evidenciar especificidades e também semelhanças no perfil dos grupos mencionados.

Como vimos, a dimensão religiosa é um elemento marcante nas identidades dos jovens religiosos - católicos e principalmente evangélicos - mas também se faz presente, de alguma forma, entre o grupo dos sem-religião, embora que com nuances diferentes e com um maior afastamento da instituição religiosa. É dentre os jovens deste último grupo, inclusive, que as aprendizagens promovidas pelo curso de Graduação parecem promover maiores influências no que se refere às concepções religiosas. Ainda, vimos que a vinculação à religião acaba se articulando, de alguma forma, à própria dimensão política que constitui as identidades desses jovens. Isso porque as concepções e as vivências relacionadas ao âmbito da política apresentaram variações em função da vinculação religiosa declarada, como pudemos verificar. Para além destas e de outras considerações anteriormente problematizadas a partir da empiria, gostaríamos ainda de ressaltar dois aspectos que consideramos relevantes, os quais parecem influenciar a dinâmica de constituição identitária dos jovens.

O primeiro deles diz respeito à relevância que a crença religiosa e a vivência na Universidade exercem na constituição das identidades dos jovens. Se, por um lado, cada grupo apresentou um perfil diferenciado - decorrente em grande parte do pertencimento religioso -, por outro lado, as aprendizagens proporcionadas pelo Ensino Superior também se mostraram marcantes, a ponto de proporcionar transformações nas concepções dos estudantes em diferentes aspectos. Nesse 
processo, contudo, não é possível identificar necessariamente a prevalência ou sobreposição de um desses elementos - religião e Universidade -, mas articulações entre ambos, construídas subjetivamente a partir das compreensões, posicionamentos e formas de participação evidenciadas pelos jovens da pesquisa. Essa constatação, em grande medida, está em consonância com parte da literatura, que vem chamando a atenção para a dinâmica de constituição das identidades que - longe de se configurarem como uma estrutura estática e imutável -, são construídas a partir do universo social, cultural e das relações concretas vivenciadas pelos sujeitos. Ademais, a despeito de uma concepção teleológica e racionalista de enclausuramento e perda de força da religião, o que podemos verificar a partir da compreensão dos jovens é que as crenças religiosas têm servido como elementos geradores de significados e de sentido a projetos individuais e coletivos.

$\mathrm{O}$ segundo aspecto a ser destacado diz respeito às inter-relações e imbricações entre as esferas do público e do privado, que decorrem das compreensões e das vivências declaradas pelos jovens. Por um lado, é possível identificar uma representação que denota uma incongruência entre essas dimensões, de modo que os elementos vinculados ao espaço público - ciência, racionalidade, política, Estado - não deveriam se misturar àqueles de âmbito privado, subjetivo, individual - como seria o caso da religião. É na esteira deste entendimento, por exemplo, que a vivência junto ao curso de Graduação teria promovido maiores transformações nas concepções sobre política do que naquelas referentes à religião. Ao mesmo tempo, como vimos, os três grupos se posicionam de forma reticente diante das possíveis aproximações entre os campos da religião e da política. Não obstante essa representação - que dicotomiza o privado e o público -, são evidentes as permeabilizações entre essas duas esferas, na medida em que a crença religiosa parece tanto ter influenciado o perfil dos três grupos - inclusive em elementos que se relacionam às concepções e ao engajamento em atividades sociopolíticas - quanto ter recebido influências de outros elementos relativos às vivências sociais e às aprendizagens proporcionadas pelo Ensino Superior. Essa 
dinâmica sinaliza para a necessidade de repensarmos a operacionalização de conceitos que orientam nosso olhar para as dimensões da religião e da política, com o intuito de apreender os fluxos, as trajetórias e os movimentos que marcam o processo de constituição das subjetividades contemporâneas.

Finalmente, destacamos que as reflexões oriundas dos resultados de nossa investigação nos permitem afirmar que as articulações entre jovens universitários, religião e política não constituem uma síntese, nem mesmo se sobrepõem, mas que suas interconexões são permeadas por processos de ressignificação e reordenamento diante das representações construídas pelos sujeitos e instituições envolvidos.

\section{REFERÊNCIAS}

ALMEIDA, R; MONTERO, P. Trânsito religioso no Brasil. Perspectiva, São Paulo, v. 15, n. 3, p. 92-101, 2001.

BAUMAN, Z. Modernidade líquida. Rio de Janeiro: Zahar, 2001.

BECK, U. Sociedade de risco: rumo a uma outra modernidade. São Paulo: Editora 34, 2010.

BEOZZO, J. O. A Igreja entre a Revolução de 1930, o Estado Novo e a redemocratização. In: FAUSTO, Boris (Org.). História Geral da Civilização Brasileira. 3. ed. Rio de Janeiro: Bertrand Brasil, 1995. p. 273-341.

BOGHOSSIAN, C.; MINAYO, M. C. Revisão sistemática sobre juventude e participação nos últimos 10 anos. Saúde e Sociedade, São Paulo, v. 18, n. 3, p. 411-423, 2009.

BOHN, S. R. Evangélicos no Brasil. Perfil socioeconômico, afinidades ideológicas e determinantes do comportamento eleitoral. Opinião Pública, Campinas, v. 10, n. 2, p. 288-338, out, 2004.

BONINI, L. F. G. Não tenho religião, apenas a crença em Deus: representações político-religiosas de jovens sem religião da Unespar. Campo Mourão, 2016. $140 f$. Dissertação (Mestrado em Sociedade e Desenvolvimento) - Programa de Pós-Graduação Interdisciplinar Sociedade e Desenvolvimento (PPGSeD). - Área de Concentração: Sociedade e Desenvolvimento,Universidade Estadual do Paraná. 
BONINI, L. F. G.; MEZZOMO, F. A.; PÁTARO, C. S. O. Representações político-religiosas de jovens sem religião. In: MEZZOMO, F.; PÁTARO, C.; HAHN, F. (Org.). Religião, cultura e espaço público. São Paulo: Olho D’água; Campo Mourão: Ed. Fecilcam, 2016. p. 149-165.

BRANDÃO, C. R. Fronteira da fé - alguns sistemas de sentido, crenças e religiões no Brasil de hoje. Estudos Avançados, São Paulo, v. 18, n. 52, p. 261-288, 2004. (Dossiê Religiões no Brasil).

BRENNER, A. K. Experiência militante e repercussões em outras esferas da vida: jovens engajados em partidos políticos. Revista NUPEM, Campo Mourão, v. 6, n. 10, p. 79-93, jan./jun, 2014.

BURITY, J. Religião e estado no caminho da confessionalização? Reflexões sobre as eleições municipais do Rio de Janeiro de 2016. Interesse Nacional, Rio de Janeiro, ano 10, n. 37, abr./jun. 2017.

BURITY, J. Religião, cultura e espaço público: onde estamos na presente conjuntura? In: MEZZOMO, F.; PÁTARO, C.; HAHN, F. (Org.). Religião, cultura e espaço público. São Paulo: Olho D’água; Campo Mourão: Ed. Fecilcam, 2016. p. 13-49.

CAMPOS, L. S. Evangélicos e política no Brasil: análise das eleições de 2002 a 2010 para a Câmara Federal. In: PÁTARO, C.; HAHN, F.; MEZZOMO, F. (Org.). Instituições e sociabilidades: religião, política e juventudes. Campo Mourão: Ed. Fecilcam, 2013. p. 63-101.

CAMURÇA, M. A sociologia da religião de Danièle Hervieu-Léger: entre a memória e a emoção. In: TEIXEIRA, F. (Org.). Sociologia da Religião. Enfoques teóricos. Petrópolis: Vozes, 2003. , p. 249-267.

CAMURÇA, M. Relações entre religião e política na juventude brasileira contemporânea. In: PÁTARO, C.; HAHN, F.; MEZZOMO, F. (Org.). Instituições e sociabilidades: religião, política e juventudes. Campo Mourão: Ed. Fecilcam, 2013. p. 31-48.

CASTELLS, M. O poder da identidade. São Paulo: Paz e Terra. 8. ed. 2013.

CASTRO, L. R. Participação política e juventude: do mal-estar à responsabilização frente ao destino comum. Revista de Sociologia e Política, Curitiba, v. 16, n. 30, p. 253-268, jun. 2008.

CASTRO, L. Reflexões sobre juventude brasileira e engajamento político-social. Revista NUPEM, Campo Mourão, v. 7, n. 12, jan./jun. 2015.

DUBAR, C. A crise das identidades: a interpretação de uma mutação. Porto: Edições Afrontamento, 2006.

DUSSEL, E. História liberationis: 500 anos de história da igreja na américa latina. São Paulo: Paulinas, 1992. 
FERNANDES, S. R. A. Adesão religiosa no segmento juvenil: apolitização ou reinvenção da política? Revista Universidade Rural, Seropédica, v. 29, n. 2, p. 152-165, jul./dez. 2007. (Série Ciências Humanas).

FERNANDES, S. R. A. Expressões políticas e crenças religiosas em jovens sem religião. In: PÁTARO, C.; HAHN, F.; MEZZOMO, F. (Org.). Instituições e sociabilidades: religião, política e juventudes. Campo Mourão: Ed. Fecilcam, 2013. p. 9-30.

FERNANDES, S. R. A. Juventude nas igrejas e fora delas: crenças, percepções da política e (des) vinculações. Tomo, Sergipe, n. 14, p. 99-126, jan./jun. 2009.

FREITAS, G. Los adolescentes como agentes de cambio social: algunas reflexiones para los psicologos sociales comunitarios. Psykhe, Chile, v. 13, n. 2, p. 131-142, 2004.

GIDDENS, A. Modernidade e identidade. Rio de Janeiro: Zahar, 2002.

GIUMBELLI, E. Em nome da caridade. Rio de Janeiro: ISER, 1993. 2 v.

HALL, S. A identidade cultural na pós-modernidade. Rio de Janeiro: DP\&A, 1999.

HERVIEU-LÉGER, D. O peregrino e o convertido: a religião em movimento. 2 ed. Petrópolis: Vozes, 2015.

LANDINELLI, J. Las finalidades públicas de la universidad en el contexto de la globalización. In: GENTILI, P. et al. Políticas de privatización, espacio público y educación en América Latina. Rosário: Homo Sapiens Ed, 2009. p. 205-224.

LUIZ, R. R. A religiosidade dos sem religião. Ciências Sociais e Religião, Porto Alegre, ano 15, n. 19, p. 73-88, jul./dez. 2013.

MACHADO, M. D. C.; BURITY, J. A ascensão política dos pentecostais no Brasil na avaliação de líderes religiosos. Dados, Rio de Janeiro, v. 57, n. 3, p. 601-631, 2014.

MARIANO, R. Mudanças no campo religioso brasileiro no Censo 2010. Debates do NER, Porto Alegre, ano 14, n. 24, p. 119-137, jul./dez. 2013.

MAYORGA, C. Juventude e participação política. Educação \& linguagens, Campo Mourão, v. 6, n. 10, p. 11-24, 2017.

MAYORGA, C.; CASTRO, L. R.; PRADO, M. A. M. Juventude e Paradoxos da política. In: MAYORGA, C.; CASTRO, L. R.; PRADO, M. A. M. (Org.). Juventude e a Experiência política no contemporâneo. Rio de Janeiro: Contra Capa, 2012. p. 261-271.

MELUCCI, A. O jogo do eu: a mudança de si em uma sociedade global. São Leopoldo: Editora Unisinos, 2004. 
MEZZOMO, F.; PÁTARO, C. Estudantes universitários no Ensino Superior público paranaense: perfil dos ingressantes na Universidade Estadual do Paraná. Campo Mourão: Ed. Fecilcam, 2015.

MORIN, E. O método 5: a humanidade da humanidade. Porto Alegre: Sulina, 2002.

NOVAES, R. A divina política. Notas sobre as relações delicadas entre religião e política. Revista USP, São Paulo, n. 49, p. 60-81, mar./maio. 2001.

NOVAES, R. Juventude, percepções e comportamentos: a religião faz diferença? In: ABRAMO, H. W; BRANCO, P. P. M. (Org.). Retratos da juventude brasileira: análises de uma pesquisa nacional. São Paulo: Fundação Perseu Abramo, 2004ª . p. 263-290.

NOVAES, R. Juventude, religião e espaço público: exemplos "bons para pensar" tempos e sinais. Religião e Sociedade, Rio de Janeiro, v. 32, n. 1, p. 184-208, 2012.

NOVAES, R. Os jovens "sem religião": ventos secularizantes, "espírito da época" e novos sincretismos - notas preliminares. Estudos Avançados, São Paulo, v. 18, n. 52, p. 321330, 2004b.

NOVAES, R. Religião e política: sincretismo entre alunos de Ciências Sociais.

Comunicações do ISER, Rio de Janeiro, n. 45, p. 62-74, 1994.

ORO, A. P. A política da Igreja Universal e seus reflexos nos campos religioso e político brasileiros. Revista Brasileira de Ciências Sociais, São Paulo, v. 18, n. 53, p. 53-69, 2003.

PAIVA, A. R. Católico, protestante, cidadão. Rio de Janeiro: IUPERJ; Belo Horizonte: UFMG, 2003.

PÁTARO, C. S. O; MEZZOMO, F. A. Religião, política e juventude: uma relação de aproximação e ressignificação. História Unisinos, São Leopoldo, v. 17, n. 2, p. 189-194, maio/ago. 2013.

PROGRAMA DAS NAÇÕES UNIDAS PARA O DESENVOLVIMENTO (PNUD). Youth Strategy 2014-2017: Empowered youth, sustainable future. New York: PNUD, 2014.

PROGRAMA DAS NAÇÕES UNIDAS PARA O DESENVOLVIMENTO, ORGANIZACIÓN IBEROAMERICANA DE JUVENTUD (PNUD/OIJ). ${ }^{\text {a }}$ Encuesta Iberoamericana de Juventudes: El futuro yallegó, 2013.

RIBEIRO, J. C. Religiosidade jovem: pesquisa entre universitários. São Paulo: Loyola; Olho d'Água, 2009.

RIBEIRO, R. J. Política e juventude: o que fica da energia. In: NOVAES, R.; VANNUCHI, P. (Org.). Juventude e sociedade: trabalho, educação, cultura e participação. São Paulo: Perseu Abramo, 2004. p. 19-33. 
RODRIGUES, D. S. Os sem religião nos censos brasileiros: sinal de uma crise do pertencimento institucional. Horizonte, Belo Horizonte, v. 10, n. 28, p. 1130-1153, out./dez. 2012.

RODRIGUES, G. A.; FUKS, M. Grupos sociais e preferência política: O voto evangélico no Brasil. Revista Brasileira de Ciências Sociais, v. 30, n. 87, p. 115-129, fev. 2015.

SANCHIS, P. (Org.). Catolicismo: modernidade e tradição. São Paulo: Loyola, 1992.

SANCHIS, P. O repto pentecostal à "Cultura Católico-Brasileira”. Revista de Antropologia, São Paulo, v. 37, p. 145-181, 1994.

SANTOS, B. S. A Universidade no século XXI: para uma reforma democrática e emancipatória da Universidade. 3 ed. São Paulo: Cortez, 2011.

SEVERINO, A. J. Expansão do Ensino Superior: contextos, desafios, possibilidades. Avaliação, v. 14, n. 2, p. 253-266, jul. 2009.

SIMÕES, P. Religião e política entre alunos de Serviço Social (UFRJ). Religião e Sociedade, Rio de Janeiro, v. 27, n. 1, p. 175-192, 2007.

SOUZA, L. A. G. As várias faces da Igreja Católica. Estudos Avançados, São Paulo, v. 18, n. 52, p. 77-95, 2004.

STEIL, C.; ALVES, D; HERRERA, S. Religião e política entre os alunos de Ciências Sociais. Debates do NER, Porto Alegre, n. 2, p. 9-35, 2001.

TEIXEIRA, F. Faces do catolicismo brasileiro contemporâneo. Revista USP, São Paulo, n. 67, p. 14-23, set./nov. 2005.

VITAL DA CUNHA, C.; LOPES, P. V. L.; LUI, J. Religião e política: medos sociais, extremismo religioso e as eleições 2014. Rio de Janeiro: Fundação Heinrich Böll; ISER, 2017. 